\title{
PENGARUH PUBLIC RELATION, ADVERTISING, DAN WORD OF MOUTH TERHADAP BRAND AWARENESS PRODUK UMKM: STUDI KASUS PADA TOKO X CAKE AND BAKERY
}

\author{
Daniel Joel Immanuel Kairupan \\ Olivia Ayu Yovanda \\ STIE YKPN Yogyakarta \\ Email korespondensi: danielkairupan@gmail.com
}

\begin{abstract}
ABSTRAK
Pemasaran merupakan sebuah aktivitas yang telah biasa terjadi dalam perusahaan untuk menciptakan, mengkomunikasikan, menyampaikan serta menawarkan produk atau jasa yang bernilai kepada konsumen. Untuk mendapatakan perhatian dari konsumen, perlu adanya strategi pemasaran dari perusahaan yang dapat menggambarkan tingkat kesadaran konsumen terhadap produk yang ditawarkan atau brand awareness. Brand awareness merupakan suatu sikap positif yang diberikan masyarakat kepada perusahaan. Brand awareness dipengaruhi oleh beberapa faktor, antara lain public relation, advertising, dan word of mouth. Perusahaan perlu memperhatikan faktor-faktor yang mempengaruhi brand awareness sehingga awareness yang dihasilkan tinggi. Penelitian ini bertujuan untuk mengetahui sekaligus menjelaskan pengaruh public relation, advertising, dan word of mouth terhadap brand awareness di Toko $\mathrm{X}$ Cake and Bakery. Penulis memilih perusahaan ini dikarenakan perusahaan tersebut saat ini memiliki permasalahan pada penguatan brand awareness. Jumlah sampel yang digunakan adalah sebanyak 160 responden yang terdiri dari pelanggan Toko X maupun yang bukan pelanggan. Pengumpulan data dilakukan dengan cara menyebarkan kuesioner secara online. Teknik analisis yang digunakan yaitu analisis regresi linear berganda. Metode pengujian hipotesis menggunakan alat bantu program SPSS v26.0. Setiap variabel yang diuji telah valid dan reliabel, serta telah layak secara model menurut uji asumsi klasik. Hasil penelitian menunjukkan bahwa variabel public relation, advertising, dan word of mouth berpengaruh positif dan signifikan terhadap brand awareness.
\end{abstract}

Kata kunci: public relation, advertising, word of mouth, brand awareness

\begin{abstract}
Marketing is an activity that is common in companies to create, communicate, deliver and offer products or services of value to consumers. To get the attention of consumers, it is necessary to have a marketing strategy from the company that can describe the level of consumer awareness of the products offered or brand awareness. Brand awareness is a positive attitude given by the community to the company. Brand awareness is influenced by several factors, including public relations, advertising, and word of mouth. Companies need to pay attention to the factors that affect brand awareness so that the awareness generated is high. This study aims to determine as well as explain the influence of public relations, advertising, and word of mouth on brand awareness at X Cake and Bakery Stores. The author chose this company because the company currently has problems in strengthening brand awareness. The number of samples used were 160 respondents consisting of customers of Store X and non-customers. Data was collected by distributing online questionnaires. The analysis technique used is multiple linear regression analysis. The hypothesis testing method uses the SPSS v26.0 program tool. Each variable tested was valid and reliable, and was modelly feasible according to the classical
\end{abstract}


JRMB, Volume 16, No. 1, Juni 2021

assumption test. The results showed that the variables of public relations, advertising, and word of mouth had a positive and significant effect on brand awareness.

Kata kunci: public relation, advertising, word of mouth, brand awareness

\section{PENDAHULUAN}

Pemasaran menjadi salah satu kunci utama dalam meningkatkan penjualan suatu produk atau jasa yang menyatukan antara pembeli dan penjual. Dalam proses pemasaran terdapat beberapa proses penunjang mengenai proses menciptakan, mengkomunikasikan, menyampaikan dan menawarkan produk atau jasa yang bernilai dari perusahaan ke konsumen. Tujuan perusahaan melakukan proses pemasaran adalah untuk meningkatkan penjualan suatu produk yang nantinya akan mempengaruhi peningkatan laba. Masing-masing perusahaan perlu mengetahui taktik apa saja yang cocok dan efektif bagi produkproduk atau segmen pasar yang ada. Dengan penerapan strategi pemasaran yang diterapkan dengan tepat akan sangat efektif dan efisien guna memudahkan konsumen dalam menerima pesan yang perusahaan ingin sampaikan.

Pemasaran merupakan salah satu kegiatan yang dilakukan oleh perusahaan untuk mempertahankan kelangsungan hidupnya, untuk terus berkembang dan mendapatkan keuntungan. Kegiatan pemasaran perusahaan harus dapat memberikan kepuasan kepada konsumen atau pelanggan jika menginginkan produknya terus dikonsumsi dan mendapatkan pandangan yang positif dari konsumen (Wasil, 2017).

Pemasaran harus dilakukan dengan konsep yang modern yaitu dengan cara berorientasi pada pasar dan pelanggan karena pemasaran tersebut adalah tombak keberhasilan suatu usaha (Kotler dan Amstrong, 2016). Sementara itu Listyawati (2016) dalam penelitiannya menyatakan bahwa promosi merupakan faktor yang menentukan keberhasilan dari pemasaran. Seperti media yang digunakan, strategi pemasaran yang diterapkan, sampai penerapannya terhadap produk. Hal ini sangat perlu untuk dicermati, karena sebaik apapun kualitas suatu produk, apabila konsumen belum pernah mendengarnya dan tidak tahu bahwa produk tersebut akan bernilai dan berguna, maka konsumen tidak akan pernah membelinya.

Untuk memperkuat keyakinan konsumen akan produk dapat dipengaruhi oleh berbagai macam strategi yang sudah dirancang sebelumnya. Misalnya dengan memberikan pelayanan yang prima (service excellence), membangun hubungan yang baik dengan konsumen (public relations), melakukan promosi berupa pengiklanan baik di sosial media atau melalui media lainnya, dan dapat dengan cara melakukan stratehi dari mulut ke mulut (word of mouth). Berbagai strategi dan cara digunakan untuk mempertahankan pelanggan lama ataupun bisa menjaring target pasar yang baru, hal tersebut dilakukan untuk melakukan promosi secara tidak langsung dan memperluas jaringan pelanggan yang loyal. Sehingga setiap perusahaan akan berupaya untuk memperkuat strategi pemasaran dengan cukup berhati-hati agar dapat memperoleh laba perusahaan dan pangsa pasar yang semakin luas.

Salah satu hal yang cukup berpengaruh terhadap keunggulan suatu merk perusahaan yaitu hubungan masyarakat atau public relation. Dengan adanya public relation, perusahaan bisa membangun hubungan yang baik dengan konsumen seperti menanggapi keluhan pelanggan, komunikasi yang tetap terjaga antar konsumen dengan pelanggan, dan memperluas jaringan konsumen. Hal tersebut ditegaskan oleh Mulyana (2007) dalam risetnya yang mengatakan bahwa public relation adalah untuk menciptakan citra, baik perusahaan sehingga dapat menghasilkan kesetiaan publik terhadap produk yang ditawarkan oleh perusahaan. Melalui public relation, perusahaan juga dapat mempengaruhi calon konsumen 
dalam membentuk persepsi brand perusahaan itu sendiri seperti yang dijelaskan oleh John E. Marston (1963) public relation is planned, perusasive communication designed to influence significant public. Public relation juga merupakan bagian penting dalam hubungan organisasi dengan eksternal perusahaan, dijelaskan oleh Ishak (2012) yang mengatakan bahwa public relation dipandang memiliki fungsi vital sebagai suatu penghubung antara organisasi dengan publik. Dari public relation inilah manajemen dapat menerima dan mengolah informasi yang ada untuk kemudian mengambilan keputusan strategis dalam rangka mengembangkan perusahaan.

Selanjutnya hal yang juga sangat penting adalah advertising atau pengiklanan yang juga sangat berpengaruh terhadap kesadaran merek (brand awareness). Dampak dari penggunaan internet marketing misalnya sosial media, dapat menanamkan suatu merek atau produk kedalam benak konsumen, sehingga masyarakat mengerti akan keberadaan merk tersebut. Advertising melalui sosial media juga sekaligus dapat menjadi sarana secara tidak langsung promosi dari satu orang ke orang lain atau biasa dikenal dengan pengiklanan mulut ke mulut (word of mouth). Menurut Azaria et al (2014) word of mouth sendiri merupakan strategi yang paling sederhana dan tidak mengeluarkan biaya dalam kegiatannya namun dapat memperoleh efektivitas yang sangat besar. Promosi ini menjadi sangat signifikan ketika testimoni seseorang terhadap produk dan pelayanan baik tetapi promosi ini juga bisa menjadi bumerang bagi perusahaan apabila perusahaan dalam pelayanannya tidak maksimal.

Sebuah perusahaan yang bergerak di bidang industri cake and bakery yaitu TOKO X yang terletak di Yogyakarta sudah unggul dalam hal kualitas, namun saat ini tengah mengalami permasalahan pada penguatan brand awareness. Hal ini terbukti dari masih banyaknya masyarakat yang belum sadar akan keberadaan merek ini, dan hanya beberapa konsumen yang tahu akan keberadaan merek ini dikarenakan strategi word of mouth dan pengiklanan yang hanya memiliki jangkauan rendah di daerah tertentu. Kurangnya branding atau promosi membuat TOKO $\mathrm{X}$ kurang dikenal dikalangan masyarakat, sedangkan untuk memperkenalkan dan menanamkan merek dalam benak konsumen dibutuhkan promosi berupa public relation, advertising (social media marketing), dan juga word of mouth. Peningkatkan promosi bertujuan untuk memperluas jangkauan konsumen, sehingga memungkinkan untuk perusahaan dan produk yang dijual lebih dikenal oleh publik. Namun, disamping kurangnya promosi, TOKO X memiliki keunggulan dari segi kualitas. Keunggulan kualitas ini membuat TOKO X cukup mampu untuk bersaing diluar pangsa pasarnya yang dibuktikan dengan meningkatnya penjualan produk dari tahun ke tahun. Tak hanya itu, TOKO $X$ juga kerap mendapatkan penghargaan, contohnya dalam lomba tingkat nasional yang diadakan oleh Bogasari Award dan TOKO X adalah salah satu dari 15 UMKM yang memenangkan lomba tersebut.

Kegiatan promosi tersebut dilakukan untuk meningkatkan kesadaran masyarakat ataupun calon konsumen terhadap produk TOKO $\mathrm{X}$ karena brand awareness sangatlah penting bagi perusahaan mengingat banyaknya persaingan ketat dalam industri yang sama. Seiring berjalannya waktu, persaingan yang ketat tersebut menuntut adanya gerakan inovatif perusahaan dalam rangka meningkatkan promosinya dengan memaksimalkan penggunaan teknologi, maksimisasi sumber daya dalam memperkenalkan merek sebuah perusahaan dan menjaga hubungan yang baik dengan perusahaan. Hal terakhir yang tidak kalah penting yaitu menjaga dan mempertahankan kualitas setiap roti yang diproduksi dan dijual, karena kualitas bisa menjadi dampak yang sangat baik juga bisa menjadi sangat buruk bagi perusahaan karena setiap konsumen 
yang mengonsumsi produk akan memberikan testimoninya kepada orang lain.

Berdasarkan pemaparan tersebut, dilakukan penelitian ini mengingat pentingnya pemasaran bagi perusahaan terhadap kesadaran merek kepada masyarakat dan calon konsumen. Maka dari itu dibuatlah penelitian ini dengan judul "Pengaruh Public Relation, Advertising, dan Word of Mouth terhadap Brand Awareness"

\section{TINJAUAN LITERATUR}

\section{Brand Awareness}

Kesadaran merek (brand awareness) artinya kemampuan calon konsumen atau masyarakat dalam mengingat dan mengenali suatu merek dari suatu produk ataupun perusahaan (Rangkuti, 2002). Rangkuti menambahkan bahwa kesadaran merek merupakan suatu daya dari seorang potential buyer dalam mengenali dan mengingat (recall) merek yang merupakan bagian dari suatu kelompok produk. Seturi (2018) menambahkan bahwa dalam lingkungan modern, suatu produk diakui sebagai elemen terpenting dari teori pemasaran. Namun kesuksesan branding tergantung pada hubungan pembeli dengan merk. Karena konsumen memiliki kemampuan dalam mengingat dan mengaitkan suatu merek dengan jenis produknya, yang mana hal ini biasa disebut dengan brand awareness.

Keke (2015) menjelaskan bahwa kesadaran merek mencakup diferensiasi kualitas yang membedakan produk dari pesaing. Kesadaran merupakan dasar dari semua kaitan merek dengan bagian lainnya yang menandakan keakraban dan komitmen potensial terhadap merek. Produk ataupun jasa yang mempertahankan tingkat brand awareness yang tinggi akan menghasilkan jauh lebih banyak kenaikan penjualan. Selain itu brand awareness merupakan kunci bagi sebuah merek untuk mendapatkan posisi tersendiri di mata konsumen (Ramadayanti, 2019).

\section{Public Relation}

Public relation merupakan bagian dari upaya pengenalan merek atau produk kepada konsumen yang termasuk dalam aktivitas promosi dengan tujuan membangun hubungan dan citra perusahaan supaya masyarakat mengenal dengan baik. Kotler dan Amstrong (2016) memperkuat penjelasan mengenai public relation dengan menjelaskan bahwa public relation is building good relations with various circles to get the desired publicity, build a great corporate brand image, and handle or deal with rumors, news and bad events yang artinya adalah hubungan masyarakat menciptakan hubungan yang baik dengan berbagai kalangan untuk menerima publisitas yang diinginkan, membangun citra yang baik, dan menangani atau menghadapi rumor, berita, dan kejadian yang tidak menyenangkan.

Hubungan masyarakat penting bagi berlangsungnya sebuah komunikasi antar perusahaan dan publik, faktanya perusahaan yang memiliki citra baik dimata masyarakat akan selalu dipercaya. Melalui komunikasi yang terintegrasi memungkinkan sebuah merek atau perusahaan membangun hubungan yang baik dengan publik atau masyarakat hingga memudahkan penjangkauan target pasar baru. Pengaruh hubungan masyarakat terhadap kesadaran merek dimulai dari komunikasi yang terbentuk dari perusahaan kepada publik yang seiring berjalannya waktu akan semakin kuat dan bisa membawa dampak positif bagi perusahaan (Hariyanto, 2017).

Melalui penerapan public relation masyarakat diharapkan akan dengan mudah mengetahui informasi yang ada terkait produk, merek, atau perusahaan begitu juga sebaliknya, melalui public relation perusahaan akan mampu membaca kebutuhan pasar, membangun hubungan kuat, melihat peluang melalui kebutuhan dan keinginan konsumen, serta menjadi mitra terpercaya antara kedua belah pihak dalam menjalankan bisnis. Hasil penelitian Keke (2015) menyatakan bahwa public 
relation berpengaruh positif terhadap brand awareness. Berdasarkan uraian di atas, dirumuskan hipotesis sebagai berikut:

H1: Public relation berpengaruh positif terhadap brand awareness.

\section{Advertising}

Advertising atau pengiklanan merupakan salah satu bentuk promosi yang paling banyak digunakan di perusahaan dalam mempromosikan produknya (Heridiansyah, 2012). Pengiklanan merupakan strategi ampuh dalam mempromosikan produk, bukan hal yang mengejutkan apabila penjualan dapat meningkat dengan signifikan karena adanya pengiklanan dari perusahaan. Tanpa adanya pengiklanan maka perusahaan akan kesulitan dalam menjaring konsumen dalam cakupan yang luas dan pertumbuhan penjualan meningkat secara signifikan. Periklanan juga berguna sebagai informasi mengenai suatu produk baik kegunaan, manfaat, dan informasi lainnya.

Tingkatan dari brand awareness seorang konsumen dibutuhkan untuk menarik dan menciTokoakan pembelian yang bervariasi yang harus disesuaikan dengan proses pembuatan brand awareness serta dimana dibuatnya keputusan itu untuk kategori produk tertentu (Bangun dan Saputri, 2016). Publisitas penjualan secara personal dan promosi sebuah penjualan dapat meningkatkan kesadaran masyarakat akan suatu merek, namun advertising juga memiliki peranan yang sama besarnya dengan metode lainnya dalam peningkatan brand awareness. Melalui advertising dengan cara apapun akan mempengaruhi tingkat awareness masyarakat terhadap merek atau sebuah produk, ketika sebuah iklan dipublikasikan secara terus menerus akan mempengaruhi pikiran dan alam bawah sadar masyarakat dan dengan begitu kesadaran merek bisa terbentuk secara alami. Hal itu yang perlu diperhatikan perusahaan dalam membuat iklan terkait produk dan mereknya, pasalnya iklan dengan kualitas baik akan selalu terngiang dalam benak masyarakat dan akan membekas sehingga pesan secara efektif akan tersampaikan kepada publik.

Tidak hanya itu, iklan tidak hanya berhenti sampai di distribusi informasi, tetapi iklan berperan lebih jauh lagi yaitu untuk membujuk dan mempengaruhi orang untuk mengambil keputusan pembelian melalui daya tarik rasional maupun emosional Periklanan sebagai bagian yang melekat pada bauran promosi yang mempengaruhi penjualan produk seperti halnya variabel-variabel bauran lainnya. Bersama-sama dengan produk atau merek, harga, saluran atau outlet distribusi dan penjualan pribadi guna mencapai tujuan pemasaran (Sawant, 2012). Iklan lewat social media juga membuat konsumen lebih dekat dan akrab dengan perusahaan dan produk yang ditawarkan perusahaan. Konsumen akan merasa puas dan percaya terhadap kualitas produk perusahaan tertentu, dari situ konsumen akan lebih mudah memutuskan untuk membeli produk tersebut. Hal ini didasarkan pada kepercayaan yang terciTokoa dari pengenalan produk melalui iklan itu sendiri. (Rufaida dan Suyanto, 2019).

Pengaruh yang signifikan dan juga positif antara advertising dan kesadaran merek hal ini dinyatakan oleh hasil penelitian Mohammad Pambudy Ary Wicaksono dan Ni Ketut Seminari (2016) dan Yulianti Keke (2015). Sehingga dapat dirumuskan menjadi hipotesis seperti berikut:

$\mathrm{H} 2$ : Advertising berpengaruh positif terhadap brand awareness

\section{Word of Mouth}

Word of mouth pada dasarnya merupakan suatu pesan mengenai pengalaman mengonsumsi produk, ataupun tentang perusahaan itu sendiri, dalam bentuk komentar dari mulut ke mulut terkait fungsi produk, pelayanan prima, kejujuran, performa pelayanan serta hal lainnya yang dapat dirasakan dan menjadi suatu pengalaman oleh seseorang yang disampaikan kepada orang lain. Pada dasarnya tiap kali konsumen mengonsumsi 
JRMB, Volume 16, No. 1, Juni 2021

ataupun memiliki pengalaman terhadap suatu produk atau jasa layanan akan memberikan testimoninya baik dari segi kualitas, pelayanan yang didapatkan, dan segala hal yang berkaitan dengan produk kepada orang-orang terdekat yang memiliki hubungan khusus secara langsung (Wicaksono dan Seminari, 2016).

Word of mouth juga berbicara mengenai pembicaraan yang secara alami terjadi antar orang-orang. Menurut Nurhaeni (2014) kegiatan word of mouth dilakukan untuk berbagi gagasan, opini, serta informasi oleh konsumen kepada orang didekatnya mengenai produk ataupun jasa yang sudah dibeli dan digunakan sekaligus melalui kegiatan ini konsumen jadi mengerti kualitas suatu produk. Word of mouth merupakan strategi tradisional yang kuat dalam menjaring pelanggan. Strategi ini dianggap menarik karena strategi ini memadukan biaya yang rendah dan juga memiliki tingkat komunikasi antar individu yang cepat dan sigap baik melalui internet atau berbagai macam media lainnya (Wicaksono and Seminari 2016).

Peranan word of mouth sangat menguatkan kesadaran merek terhadap masyarakat dan publik, terbukti dari banyaknya konsumen potensial yang sadar akan keberadaan suatu perusahaan dan memutuskan untuk membeli suatu produk karena telah berinteraksi dengan konsumen lain yang telah terlebih dahulu menceritakan pengalamannya terkait produk yang dijajal. Bentuk ketenaran suatu produk atau layanan juga merupakan dampak dari komunikasi word of mouth itu sendiri dan disaat itu juga kesadaran merek suatu produk terbentuk dalam masyarakat. Menurut hasil penelitian dari Mohammad Pambudi Ary Wicaksono dan Ni Ketut Seminari (2016) dan Siti Maria (2019) menyatakan word of mouth berpengaruh positif terhadap brand awareness. Sehingga dapat disimpulkan sebagai berikut:

H3: Word of Mouth berpengaruh positif terhadap Brand Awareness 


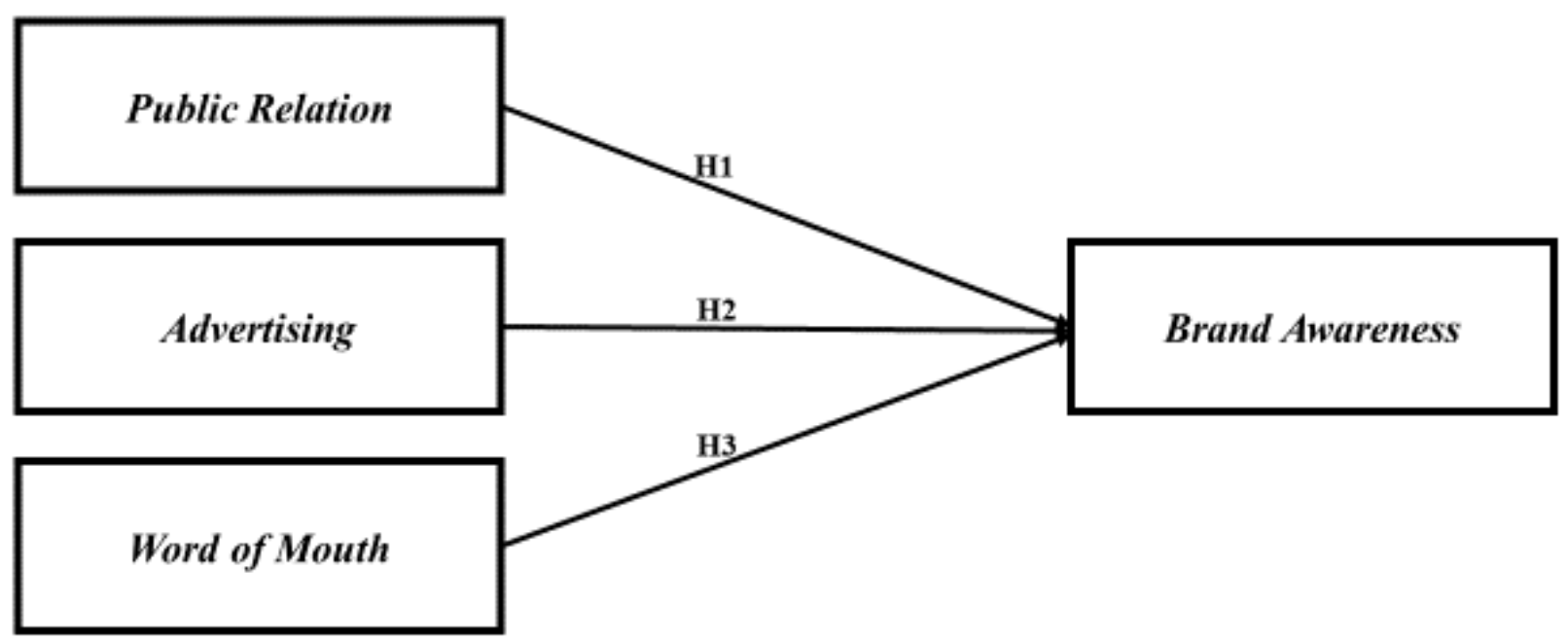

Gambar 1. Model Penelitian

\section{METODE PENELITIAN}

Penelitian ini menggunakan unit analisis sebuah badan usaha yang berkecimpung di dunia industri kuliner yaitu TOKO X yang memiliki masalah dalam hal penguatan brand awareness produknya terhadap masyarakat. Penelitian ini difokuskan pada hubungan masyarakat, iklan, dan pemasaran dari mulut ke mulut terhadap perusahaan terkait. Unit analisis merupakan masalah krusial dan penting untuk ditentukan sehingga validitas dan reliabilitas data tetap terjaga. Maka dari itu, penelitian ini hanya terbatas pada objek yang diteliti yang diharapkan tidak akan meluas pada persoalan yang tidak berhubungan dengan hal yang dikaji.

Populasi yang digunakan di dalam penelitian ini yaitu semua orang yang pernah membeli produk ataupun berkaitan dengan TOKO X di Yogyakarta. Populasi ini masuk dalam jenis tidak terbatas (infinite) karena tidak diketahui jumlah banyaknya populasi. Teknik yang digunakan yaitu purposive sampling yaitu teknik penentuan sampel dengan suatu hal yang dipertimbangkanan (Sugiyono, 2010) dan hal yang menjadi pertimbangan adalah masyarakat yang memiliki kaitan dengan perusahaan baik pelanggan, calon konsumen, dan sebagainya. Populasi di dalam penelitian ini sangat banyak, menurut Algifari (2013) untuk menentukan besarnya sampel dalam menentukan estimasi proporsi populasi dengan prosedur untuk estimasi rata-rata. Sebanyak 160 responden digunakan dalam penelitian ini dengan tetap mempertimbangkan bahwa jumlah sampel tersebut cukup representatif dalam mewakili populasinya.

Data dikatakan normal apabila nilai signifikansi lebih dri 0,5\% (sig. > 0,5\%), Pengujian ini dapat dilihat melalui nilai VIF, apabila nilai VIF $<10$ maka terjadi multikolinearitas dalam regresi, tetapi jika nilai VIF > 10 maka tidak terjadi multikolinearitas dalam regresi. Apabila nilai $>$ 0,05 maka tidak terjadi heterokedastisitas, sebaliknya jika nilai $<0,05$, maka terjadi heteroskedastisitas dalam regresi dan perlu dikoreksi.

\section{HASIL ANALISIS DAN PEMBAHASAN \\ Dalam upayanya memperoleh kelengkapan data, penelitian ini menggunakan google form sebagai alat bantu dalam menyebarkan dan membagikan kuesioner kepada responden secara online.}


JRMB, Volume 16, No. 1, Juni 2021

Karakteristik responden yaitu meliputi nama, jenis kelamin, umur, dan pekerjaan. Dari informasi yang bersumber dari kuesioner, mayoritas responden berjenis kelamin

perempuan sebesar (65\%). Rentang usia terbesar dengan usia 30-40 tahun (35,64\%) dan pekerjaan sebagai karyawan memiliki jumlah paling besar dengan $40 \%$.

Tabel 1. Tabel Uji Validitas

\begin{tabular}{|c|c|c|c|c|}
\hline Variabel & Item & $\mathbf{r}_{\text {hitung }}$ & $\mathbf{r}_{\text {tabel }}$ & Ket. \\
\hline \multirow{4}{*}{$\begin{array}{l}\text { Public Relation } \\
\text { (H1) }\end{array}$} & H1.1 & 0,710 & 0,1501 & Valid \\
\hline & H1.2 & 0,843 & 0,1501 & Valid \\
\hline & H1.3 & 0,724 & 0,1501 & Valid \\
\hline & $\mathrm{H} 1.4$ & 0,720 & 0,1501 & Valid \\
\hline \multirow{5}{*}{ Advertising (H2) } & H2.1 & 0,812 & 0,1501 & Valid \\
\hline & H2.2 & 0,814 & 0,1501 & Valid \\
\hline & $\mathrm{H} 2.3$ & 0,796 & 0,1501 & Valid \\
\hline & $\mathrm{H} 2.4$ & 0,848 & 0,1501 & Valid \\
\hline & $\mathrm{H} 2.5$ & 0,785 & 0,1501 & Valid \\
\hline \multirow{5}{*}{ Word of Mouth (H3) } & H3.1 & 0,717 & 0,1501 & Valid \\
\hline & H3.2 & 0,760 & 0,1501 & Valid \\
\hline & H3.3 & 0,682 & 0,1501 & Valid \\
\hline & H3.4 & 0,730 & 0,1501 & Valid \\
\hline & H3.5 & 0,627 & 0,1501 & Valid \\
\hline \multirow{5}{*}{ Brand Awareness } & Y.1 & 0,766 & 0,1501 & Valid \\
\hline & Y.2 & 0,482 & 0,1501 & Valid \\
\hline & Y.3 & 0,797 & 0,1501 & Valid \\
\hline & Y.4 & 0,864 & 0,1501 & Valid \\
\hline & Y.5 & 0,891 & 0,1501 & Valid \\
\hline
\end{tabular}

Sumber: Data diolah

Jumlah seluruh responden penelitian ini yaitu sebanyak 160 responden dan diketahui nilai $r_{\text {tabel }}$ yaitu 0,150 . sehingga untuk setiap item pertanyaan dikatakan valid apabila koefisien validitas $>r_{\text {tabel }}$ yaitu 0,150. Berdasarkan tabel 1 berikut merupakan hasil pengolahan validitas data yang menunjukkan bahwa seluruh unit pernyataan dalam angket menunjukkan valid lantaran $\mathrm{r}_{\text {hitung }}>0,150$ dan semua item dari pernyataan dapat digunakan sebagai alat pengumpulan data yang valid.

Tabel 2. Uji Reliabilitas

\begin{tabular}{ccc}
\hline Variabel & Nilai Cronbach's Alpha & Keterangan \\
& & \\
\hline Public Relation & 0,797 & Reliabel \\
Advertising & 0,864 & Reliabel \\
Word of Mouth & 0,741 & Reliabel \\
Brand Awareness & 0,829 & Reliabel \\
\hline
\end{tabular}

Sumber: Data diolah

Dari Tabel 2, hasil pengujian reliabilitas di dalam penelitian ini dapat dilihat bahwa semua item pertanyaan pada setiap variabel memiliki alpha $>0,7$ yang 
berarti dapat diambil kesimpulan alat ukur yang digunakan sudah reliabel

Tabel 3. Uji Hipotesis

\begin{tabular}{ccc}
\hline Variabel Independen & T-Hitung & Nilai Signifikansi P Value \\
\hline Public Relation (X1) & 5,441 & 0,000 \\
Advertising (X2) & 2,950 & 0,004 \\
Word of Mouth (X3) & 7,876 & 0,000 \\
\hline
\end{tabular}

Tingkat kepercayaan yang digunakan sebesar 95\% dengan nilai a sebesar 0,05 kemudian dari perhitungan yang sudah dilakukan, diketahui nilai T-tabel sebesar 1,975. Hasil uji t dapat dilihat dari tabel yang sudah disajikan, diketahui bahwa nilai signifikansi untuk variabel public relation adalah 0,000 $<0,05$ dan nilai t hitung 5,441 > 1,975 yang berarti hipotesis alternatif diterima dan dapat disimpulkan bahwasannya ada pengaruh antar variabel public relation terhadap Y. Selanjutnya, yaitu variabel advertising dengan nilai signifikansi $0,004<0,05$ dan $t$ hitung sebesar 2,950 > 1,975 yang berarti hipotesis alternatif diterima dan terdapat pengaruh antara X2 dengan Y. Hasil uji t terakhir adalah variabel word of mouth dengan nilai signifikansi $0,000<0,05$ dan nilai thitung sebesar 7,876 $>1,975$ yang berarti juga terdapat pengaruh antara variabel X3 dengan Y. Dapat disimpulkan bahwa semua uji t pada setiap variabel bebas mempunyai pengaruh ataupun dampak secara parsial atas variabel terikat.

Tabel 4. Uji Determinasi $\left(\mathbf{R}^{2}\right)$

\begin{tabular}{cc}
\hline $\mathrm{R}$ & $\mathrm{R}^{2}$ \\
\hline 0,815 & 0,664 \\
\hline
\end{tabular}

Pada penelitian ini diketahui hasil uji adjusted $\mathrm{R}^{2}$ sebesar 0.658 dan dapat disimpulkan bahwa dalam variabel independen public relation, advertising, dan word of mouth mampu menjelaskan besarnya pengaruh terhadap variabel terikat brand awareness sebesar 65,8\% dan 34,2\% lainnya dipengaruhi faktor yang berbeda yang tidak diteliti di dalam penelitian ini.

\section{PEMBAHASAN}

Hipotesis satu menunjukan bahwa variabel public relation berpengaruh positif pada brand awareness. Keke (2015) dalam penelitiannya menjelaskan bahwa terdapat pengaruh yang positif signifikan antara variabel public relation terhadap brand awareness. Hal yang menyebabkan besarnya pengaruh public relations terhadap kesadaran merek konsumenialah karena kegiatan dari public relation itu sendiri yang dilakukan tidak hanya pada kegiatan layanan masyarakat sekitar saja. Ruslan (2001) juga menambahkan bahwa terdapat pengaruh positif antara variabel public relations dan brand awareness. Dengan menangani keluhan pelanggan secara maksimal, memberikan layanan yang terbaik dalam pengelolaan customer, turut serta dalam hal donasi dan berkontribusi di lingkungan masyarakat, sponsor dalam acara tertentu yang dapat meningkatkan brand awareness masyarakat terhadap perusahaan.

Hipotesis dua menunjukan bahwa variabel advertising berpengaruh positif pada brand awareness. Penelitian ini juga didukung oleh hasil penelitian dari Wicaksono dan Seminari (2016) yang 
menyatakan hal yang sama bahwa advertising memiliki pengaruh variabel yang signifikan yang ditunjukkan oleh nilai signifikansi sebesar $0.000<0,05$ dan dapat diambil kesimpulan bahwa advertising berpengaruh positif dan signifikan terhadap pembentukan brand awareness. Dzulfiqar dan Dinda (2017) juga menyebutkan bahwa kedua variabel tersebut memiliki hubungan yang signifikan.

Sementara itu, hipotesis ketiga menyatakan bahwa variabel word of mouth berpengaruh positif terhadap brand awareness. Hasil ini didukung dari Wicaksono dan Seminari (2016) yang menyatakan bahwa word of mouth sebagai aspek dalam penelitiannya. Dalam hasil penelitiannya, menunjukkan bahwa word of mouth berpengaruh positif dan signifikan terhadap brand awareness yang dibuktikan dengan nilai signifikansi yang diperoleh sebesar 0.00 yang lebih kecil dari nilai kriteria penolakan Ho pada tingkat signifikan 0,05. Dalam penelitian tersebut menjelaskan bahwa word of mouth adalah cara memanfaatkan kekuatan seseorang atau sekelompok orang dalam membangun kesadaran merek suatu produk. Mengingat banyaknya rival yang bersaing dalam industri yang sama, maka word of mouth berperan besar dalam memegang kendali kesadaran masyarakat akan suatu merek.

\section{KESIMPULAN}

Kesimpulan yang dapat ditarik dalam penelitian ini adalah variabel public relation berpengaruh terhadap brand awareness TOKO X Cake and Bakery. Dengan public relation yang baik, perusahaan dapat membangun hubungan yang baik dengan konsumen seperti menanggapi keluhan pelanggan, komunikasi yang tetap terjaga antar konsumen dengan pelanggan dan memperluas jaringan konsumen. Variabel kedua yaitu adverstising berpengaruh terhadap brand awareness Toko tersebut. Hal ini menunjukkan bahwa pengiklanan sangat penting terhadap kesadaran merek atau brand awareness. Sementara itu variabel ketiga yaitu variabel word of mouth juga berpengaruh terhadap pembentukan brand awareness. Meskipun strategi ini tergolong sederhana, namun perusahaan dapat memperoleh efektivitas yang sangat besar. Namun perusahaan juga perlu berhati-hati dalam memberikan pelayanan kepada konsumen.

Perusahaan perlu tetap menjaga kualitas layanan agar konsumen yang datang dapat memberikan testimoni yang positif mengenai produk dan jasa yang diberikan kepada kolega mereka. Sementara itu meskipun public relation tidak berfokus pada penjualan secara langsung (seperti kegiatan periklanan) namun public relation memegang peran penting seperti penyampaian informasi. Sehingga perusahaan perlu meningkatkan komunikasi dengan masyarakat secara intensif, hal itu akan mempererat hubungan antar kedua belah pihak. Untuk advertising perusahaan dapat memaksimalkan segala jenis platform pengiklanan di media sosial.

\section{REFERENSI}

Algifari. (2013). Statistika Induktif Untuk Ekonomi dan Bisnis (Edisi 3). Yogyakarta: Sekolah Tinggi Ilmu Manajemen YKPN

Azaria, Phamendyta Aldaning, Srikandi Kumadji, dan Fransisca Yaningwati. (2014). Pengaruh Internet Marketing Terhadap Pembentukan Word of Mouth dan Efektivitas Iklan dalam Meningkatkan Brand Awareness. Jurnal Administrasi Bisnis, Vol. 13 No. 1, pp. 1-7.

Bangun, Bella Tania, dan Saputri, Marhani Eka. (2016). Pengaruh Advertising terhadap Pembentukan Brand Awareness pada Zalora Indonesia.” Vol. 3, pp. 2076-2080. 
Dzulfiqar, Rafli, dan Dinda Zuliestiana. (2017). Pengaruh Advertising dan Sales Promotion melalui Media Sosial "Instagram" terhadap Keputusan Pembelian, Vol.4, pp. 1366-1374.

Febrisari, Astriana. (2011). Analisis Pengaruh Public Relations PerceTokoion terhadap Brand Image Dalam Membentuk Loyalitas Pelanggan Asuransi Garda Oto Jabodetabek. Skripsi. Fakultas Ekonomi dan Manajemen Bogor.

Hariyanto, Didik. (2009). Memenangkan Persaingan Bisnis Produk Farmasi melalui Marketing Public Relations. Jurnal Manajemen Pemasaran, Vol 4, pp. 38-44.

Heridiansyah, Jefri. (2012). Pengaruh Advertising terhadap Pembentukan Brand Awareness serta Dampaknya pada Keputusan Pembelian Produk Kecap Pedas ABC. Jurnal STIE Semarang, pp. 53-73.

Hidayat, Taufiq. (2015). Pengaruh Marketing Public Relation terhadap Loyalitas Pelanggan pada TOKO Jalur Nugraha Ekakurir (JNE) Bandung. Jurnal Ekonomi Bisnis \& Entrepreneurship, Vol. 9, pp. 102-115.

Ishak, Aswad. (2012). Peran Public Relations dalam Komunikasi Organisasi. Jurnal Komunikasi, Vol. 1, pp. 373-380.

Keke, Yulianti. (2015). Komunikasi Pemasaran Terpadu terhadap Brand Awareness. Jurnal Manajemen Bisnis Transportasi dan Logistik, Vol.2.

Kotler, Philip, dan Amstrong, Gery. (2016). Principles of Marketing. England: Pearson Education.

Listyawati, Indri Hastuti. (2016). Peran Penting Promosi dan Desain Produk dalam Membangun Minat Beli Konsumen. Jurnal Bisnis, Manajemen, dan Akuntansi, Vol. 3, pp. 62 - 70.

Maria, Siti, Tommy Pusriadi, and Yundi Permadi Hakim. (2019). The Effect of
Social Media Marketing, Word of Mouth, and Effectiveness of Advertising on Brand Awareness and Intention to Buy. Jurnal Manajemen Indonesia, Vol. 19, pp. 107-122.

Marston, John. (1963). The Nature of Public Relations. New York: McGraw-Hill. dalam Anastasia, E. (2017). "Strategi Kampanye Public Relations Dalam Meningkatkan Customer Engagement: Studi Kasus Pada Friskies\# 500catventure” Doctoral dissertation. Universitas Multimedia Nusantara.

Mulyana, Deddy. (2007). Ilmu Komunikasi: Suatu Pengantar. Bandung: Remaja Rosdakarya.

Nurhaeni, Nelly. (2014). Analisis Pengaruh Kualitas Pelayanan , Word of Mouth, dan Lokasi terhadap Keputusan Pemakaian Jasa Bengkel Jakate Motor Tangerang. Universitas Diponegoro.

Rangkuti, Freddy. (2002). Measuring Customer Satisfaction. Jakarta: Gramedia Pustaka Utama

Ramadayanti, Firda. (2019). Peran Brand Awareness terhadap Keputusan Pembelian Produk. Jurnal Studi Manajemen dan Bisnis, Vol. 6 No. 2.

Ruslan, Rosady. (2001). Manajemen Humas dan Manajemen Komunikasi. Jakarta: Grafindo Persada

Rufaida, Nabila, and Suyanto, Ama. (2019). Analysis the Impact of Digital Marketing of the Brand Awareness on E-Commerce. Vol.6, pp. 2091-2097.

Sawant, Roshni. (2012). Impact of Advertising on Brand Awareness and Consumer Preference (With Special Reference to Men`S Wear. Journal of Business and Management, Vol. 5 No. 6, pp. 54-61.

Sugiyono. 2010. Metode Penelitian Manajemen. Bandung: Alfabeta.

Suharsimi, Arikunto. 2010. Prosedur Penelitian Suatu Pendekatan Praktik. Jakarta: Rineka Cipta. 
JRMB, Volume 16, No. 1, Juni 2021

Wasil, Mohammad. 2017. Pengaruh Brand Awareness Brand Association dan Perceived Quality. Forum Ekonomi Vol. 19 No. 2.

Wicaksono, Mohammad Pambudi Ary, dan Ni Ketut Seminari. 2016. Pengaruh Iklan Dan Word Of Mouth Terhadap Brand Awareness Traveloka. E-Jurnal Manajemen Unud, Vol. 5, pp. 50985127. 
JRMB, Volume 16, No. 1, Juni 2021 
